\title{
CURRENT STATUS OF COCONUT RESEARCH IN SRI LANKA
}

\author{
RANJITH MAHINDAPALA ${ }^{1}$
}

\section{The Coconut Industry}

Coconut occupies about 410,000 ha of land in Sri Lanka, and is the largest plantation crop. The most important coconut growing area is called the "Coconut triangle" which comprises most of the districts of Puttalam. Colombo and Gampaha. Together, they account for nearly 70 per cent of the coconut lands. There are about 700,000 coconut growers, the majority of which are small-holders. About 70-75 per cent of the holdings are below 4 hectares.

The coconut processing industry consists of copra milling, desiccated coconut manufacture, fibre and charcoal production. There are over 50 oil mills and over 60 DC mills. Over 800 fibre mills are known to exist. In all, the coconut processing industry provides direct employment to about 100,000 workers.

Coconut is a major source of edible oil and fat in the daily diet of Sri Lankans. The average per capita consumption is about 105 nuts per year. Coconut supplies about 22 per cent of the daily caloric intake of an average consurner and is a major source of calories, being second only to rice.

The coconut production in 1986, 1987 and 1988 had been 3,041, 2,292 and 1,933 million nuts respectively. The value added as percentage GDP (in producing and processing) has been 2.6, 2.6 and 2.7 for these years. The average export price (FOB) per nut during these years had been Rs. 1.46, Rs. 2.64 and Rs. 4.00 respectively, while the export earnings had been Rs. 2,389, 2,140 and 1,539 million respectively.

\section{The Coconut Research Institute}

A definite proposal for a Coconut Research Scheme under the Ministry of Agriculture was entertained in 1923 and resulted in the Coconut Research Ordinance No. 29 of 1928. The Scheme was in operation in 1929, and was upgraded to the Coconut Research Institute (CRI) in 1950.

The CRI began its activities with only three technical divisions: Genetics, Chemistry and Soil Science. Since then there has been a progressive enlargement of activities resulting in the creation of more technical divisions and reorganizations.

The Coconut Development Act No. 46 of 1971 was promulgated after the establishment of the Ministry of Plantation Industries. Under this act, the Coconut Development Authority was established to coordinate the functions of the satelite Boards. A further organizational change occurred in 1978 when the government established a separate Ministry of Coconut Industries and transferred the CRI to that ministry. This ministry was abolished in 1989, and the CRI functions under the Ministry of Plantation Industries.

The functions of the CRI are: conducting and furthering scientific research in respect of the growth and cultivation of the coconut palm, coconut-based farming systems and formulate measures for preventing and controlling pests and diseases. It also provides technical advice to the estate sector (50 ac and above), advices the Coconut Development Authority and the Coconut Cultivation Board regarding developments in research and train the relevant staff to enable transfer of new technologies and supplies the required seednuts for the national planting programme.

\footnotetext{
${ }^{1}$ Director, Coconut Research Institute, Lunuwila, Sri Lanka
} 
The research activities of the CRI are organized into seven divisions: Agronomy, Crop Protection, Genetics and Plant Breeding, Soils and Plant Nutrition, Biometry, Tissue Culture and Plant Physiology. These technical divisions are serviced by a Library, the Coconut Information Centre, Information Services Unit, the Administration Division and the Estates Management Division.

The main laboratories of the CRI are located at Lunuwila. In addition to this central organization, the Institute conducts research at six other sub-stations. The CRI also has three seed gardens for the production of improved planting material. In all, there are nearly, 1,000 ha of experimental and seed garden land.

\section{Research Accomplishments}

Breeding: Some of the pioneering work on the genetic improvement of the coconut palm was initiated with the inception of the Coconut Research Scheme. Initial studies were directed to identify suitable criteria for selection of seed parents in order to provive improved planting material. On these criteria , the seed palms should have a short bunch stalks; closely set leaf scars, short, well oriented fronds; short bunch stalks; a fair number of female flowers on the inflorescences; a large number of inflorescences carried evenly round the crown; a large number of nuts, the size of the nut being of no importance as long as the number is large and weight of the husked nut high (Pieris, 1934).

Subsequently, several field studies had been undertaken to evaluate the efficiency of mass selection methods. In one of these studies, a very useful correlation between the weight of copra and weight of the husked nut had been established (Pieris, 1935). Several progeny trials planted at different locations by Pieris (1934), Raghavan (1948), Harland (1957) and Liyanage (1959) gave very useful data, which had been used extensively for genetic studies such as estimation of genetic environmental correlations, heritability values, genetic progress due to selection and the construction of a selection index (Liyanage and Sakai, 1960; Liyanage, 1967).

Controlled pollination work on coconut palms was initiated in 1947, with a view to produce improved cultivars through hybdridization. As an initial step, pollen processing was undertaken. A programme to produce inter and intra-varietal hybrids was introduced in 1949 with the objective of developing improved varieties. The first series of crosses involved Sri Lanka Tall (SLT) (female parent) and Green Dwarf (GD) palms.

However, when the palms were 11 to 12 years old, the differences between the two varieties disappeared, each aggregating about 23,500 nuts (6,100 kg copra)/ha/year (Liyanage, 1963).

A second series of crosses involving a larger number of crosses between SLT and three different colour forms of dwarfs (red, green and yellow) were planted. This trial confirmed the early flowering character of SLT x Dwarf progenies. However, the differences in production between the three types of hybrids were negligible (Manthriratne, 1971).

An important observation from the second series was that hybrids performed relatively poorly than in the first series, and it was evident that soil characteristics were involved. The hybrids performed well in deep, loamy soils whereas they performed poorly in clayey soils, subject to cracking in dry weather. Based on the progeny trials, two improved coconut varieties, CRIC 60 and CRIC 65 were released to the industry.

CRIC 60 Derived by crossing selected SLT x SLT. Late flowering (55 to 70 months), out-breeding. Hardy palms tolerating a wide range of environmental conclitions, capable of producing over 110 nuts/palm/year with about $225 \mathrm{~g}$ f copra per nut, 
under rainfed conclitions. Released to the inclustry in 1960. Recommencled for planting in all coconut growing areas.

CRIC 65 Derived by crossing selected DG x SLT. Early flowering (36 to 45 months), out-breeding, capable of producing over 120 nuts/palm/year with about $210 \mathrm{~g}$ copra per nut. Requires good soil and well-distributed rainfall. Recommencled for planting in good soils in the wet zone, in home gardens or under irrigation.

A seed garden was establis6ed in 1955 for the mass production of CRIC 60 and CRIC 65. Under good rainfall conclitions, SLT x SLT in the seed garden has given over 25,000 nuts/ha (Liyanage et al., 1988).

A multi-locational trial involving D x T hybrids and selected talls was established in 1984. Early results indicate the hybrid vigour, and this trial is likely to give comprehensive data on the performance of hybrids (Fernando and Wickramaratne, 1988).

A recent survey has revealed that the average yield from plantation of SLT x SLT amounted to over 11,000 nuts/ha/yr. The production from CRIC 65 hybrids ranged from 10,000 - 40,000 nuts/ha/yr but was inconsistent. The great variation in yield was found to be clue to soil type, rainfall (intensity and distribution) and level of management (Wickramaratne, 1988). In the breeding programme, the need to produce nut components other than kernel has been recognized in view of the importance of fibre and shell in Sri Lanka. SLT x SLT is superior in this respect (Liyanage, 1989).

Crop Protection: Since 1958 when a pupal parasite Trichopilus pupivor was first bred to control a severe outbreak of the coconut caterpillar, Opisina arenosella, the emphasis on pest management has been heavily weighted towards biological control. The value of this technique was amply clemonstrated when the coconut leaf miner Promecotheca cumingi was inadvertently introduced to Sri Lanka in 1970. Soon after introduction, the pest spread rapidly and an estimated 10,000 ha were severaly affected (Fernando, 1972).

The strategy for the control of this pest included the import, laboratory breeding and release of two parasites. The larval parasite, Dimmockia javanica and the larval-cum-pupal parasite, Pediobius parvulu were multiplied in the laboratory and released in the field. After about a year and the release of nearly 150,000 adult parasites, the pest population declined rapidly and a massive build up of parasites was noted. Within two years the pest was completely under control (Dharmadhikari et al., 1971). The loss of yield at that time was estimated to be 20 million nuts, the cost of the entire biological control prograrnme has been about US $\$ 10,000$, which has now made an annual saving of about US $\$ 80$ million (Mahindapala, 1985).

The coconut scale, Aspidiotus clestructor is also kept in control by preclators, which were initially multiplied in the laboratory and released (Mahindapala, 1978).

A considerable amount of work has been done on the biological control of the black-headed caterpillar, Opisina arenosella. In this regard, there has been a long history of both classical and augmentative biological control attempts in Sri Lanka, and a number of parasitoid species have been introduced from India. This work has been reviewed by Cock and Perera (1988) and Perera et al. (1988). The current strategy for the control of this pest is based on data obtained from long term population monitoring by the CRI. Other attempts of biological control include the use of microorganisms against Orvctes rhinoceros (Fernando and Kanagaratnam, 1987) and the use of an insect, Parauchaetes pseudoinsulata for the control of the pernicious weed, Chromolaena oclorata (see Mahindapala et al., 1982). 
The common diseases of coconut have received attention during the last 20 years or so, and control strategies have been developed. The emphasis has been to formulate cheap methods of disease control (Mahindapala, 1989).

Research work on pest control continues with a view to introduce more effective pest control measures. In this regard, integrated control measures have received attention, where insecticides are judiciously used. The difficulties of spraying insecticides to the crown of the palm have been overcome with the introduction of other techniques of application such as trunk injection (Kanagaratnarn and Pinto, 1985) or application via petiolar wells (Perera et al., 1989).

Coconut nutrition: One of the first statistically clesigned field experiments on fertilizer in Sri Lanka was laid out in the 1930's (Salgado, 1937). The results of this and several other long-term field experiments on fertilizer indicated the importance of potassium, not only for nut production but also for better copra out-turn (Salgado, 1952). These trials have also elucidated the roles of nitrogen and phosphorus. Experiments conclucted in the 1950's inclicated that the cheaper methods of surface application was as good as the traditional trench method of application. Several elegant experiments in the 1960's using radio active materials provided valuable information on the effective root zone and the uptake of fertilizer and led to precise recommenclations on the placement and application of fertilizer (Nethsinghe, 1966; Balakrishnamurthi, 1969).

Early studies at the CRI inclicated importance of fertilizer application based on nutrient removal and the foliar nutritional status of the palm (Nathanael, 1961; 1967).

The long-term experiments conclucted in the different agroclimatic zones of the country were used to formulate fertilizer recommenclations for adult-palms for different areas, taking into consideration the climate and the soil types (Loganathan and Balakrishnamurthi, 1975; 1979). Similarly, the nutritional requirements of young palms too have been cletermined (Loganathan, 1977).

Some of the pioneering work on mineral deficiencies and their correction has been carried out at the CRI (Nathanael, 1961). This and the later work enabled preparation of "nutrient maps" and identifying areas prone to deficiencies.

Some of the early work at the CRI enabled elucidation of the role of micro-nutrients in coconut nutrition. It was also possible to establish the critical levels of these nutrients in the leaf and relate such data to the nutrient status of the soil (De Silva et al., 1974).

The need to consider the economic aspects of fertilizer usage was recognized quite early. Based on these studies, economic use of fertilizers has been recommencled (Abeywardene, 1975; De-Silva and Tisdell, 1981). Also important is the work done on nutritional studies on locally available organic manures (Salgado, 1957). This work led to the use of organic manures supplemented with inorganic fertilizers (Shanmuganathan, 1985).

A recent development of considerable importance is the formulation of "Differential Fertilizer Recommenclation" based on f6liar nutrient levels. This method enables the application of only the required fertilizer, rather than a pre-cletermined fertilizer mixture (Jayasekera, 1988).

Cultural practices: Much work has been done on soil and moisture conservation in coconut lands. The practices adopted for soil and moisture conservation had been partly traditional, based more on empirical methods of trial and error (Salgado, 1958). Emphasis has been given during the last decade or so to quantify the benefits of such practices and to evaluate the economic benefits. For instance, the benefits of husk burying in coconut lands for moisture conservation have been clearly clemonstrated (Jayasekera and Loganathan, 1981; Liyanage, 1988). The need to carry 
out cultural practices and their longterm benefits in increasing coconut production, both at small-holder level and in estates have been clearly felt (Mahindapala, 1984; Henry Nimal, 1984). More recent work includes the use of cover crops and their beneficial effects on physical improvement of soil and consequent moisture holding capacity, . Both creeping covers and ground covers have been extremely beneficial, particularly in drier areas (Liyanage, 1987).

Maximising productivity of coconut lands: The CRI conducted some of the earliest trials on plant clensity and valuable information on the effect of plant density on the yield were obtained (Manthriratne and Abeywardena, 1974). Based on these results, it has been possible to recommend a range of plant densities, and the grower can choose the appropriate density depending on the climate and soil type.

In view of the large area under coconut in Sri Lanka, the need to increase productivity from coconut lands through intercropping and animal husbandry was felt and emphasized by the policy makers (Anon, 1984).

The investigational work on intercropping was pioneered by the CRI. To begin with, the CRI had a programme on pasture and fodder as intercrops under coconut.

Several pastures from similar ecological regions of the world had been introduced and these were rigorously tested in the field at several locations in the coconut growing areas. Based on the results, several pasture and fodder grasses, namely, Brachiaria milifformis, B dictyoneura, B ruziziensis, Panicum maximum and Setaria sp. have been identified as suitable for growing under coconut in wetter areas (Santhirasegaram and Ferdinandez, 1967; Ferdinandez, 1979). Techniques for the establishment and management of legume/grass mixtures have also been introduced.

Along with this work, a programme had been launched to upgrade the indigenous cattle by a series of crosses with exotic animals.

Experiments on intercropping with perennials started in the mid 1970's. This work has clearly established that intercropping with perennials and semi-perennials does not adversely affect the yield of coconut in the wet and intermediate zones of Sri Lanka receiving an annual rainfall of $1,750 \mathrm{~mm}$ or more (Liyanage, 1985; Liyanage 1984). In fact, intercropping increases coconut yields by the addition of leaf litter, retention of moisture, suppression of weeds and improved soil microbial activity.

Crops such as cacao, pepper, coffee, cinnamon, cloves etc. can either be grown separately or in mixes under coconut (Gunathilaka, 1986). The field trials have clearly indicated the economic advantage of intercropping (Mathes, 1986). However, the returns frorn certain crops such as pepper can be much higher than from seasonal crops but the payback period from seasonal crops is much shorter. In this regard, socioeconomic studies have also been carried out (Ranatunga et al., 1988).

Product technology: Some of the pioneering work on product technology had been carried out at the CRI in the 1950's and 1960's. The design of the 'Ceylon Copra Kiln', which produces high quality copra, is of utmost significance (Nathanael, 1966). This kiln is now popular in many of the coconut growing countries. The 'generator process' for the conversion of toddy into high grade vinegar (Nathanael, 1955), methods for the preparation of treacle, jaggery (Nathanael, 1970 a) and sugar on cottage scale and the preparation of non-alcoholic and alcoholic beverages (Nathanael, 1954) with coconut sap as the base material are other notable achievements.

Research on fibre and shell products was also launched during this period (Nathanael, 1970 b), and consequently, these products have now emerged as important foreign exchange earners for Sri Lanka. 


\section{The Current Research Programme}

The Institute launched a five-year research programme in 1984 based on a number of high priority research projects. These projects were identified after having taken into consideration the need for developing a programme that is dynamic and adaptable to the changing conditions. The main objectives of the prograrnme are: increase national coconut production, reduce cost of production and increase productivity frorn coconut holdings. Accordingly, nearly 20 high-priority projects were identified.

Under this prograrnme, over 100 experiments are being carried out, some of which are multi-locational. Results of some of the key investigations have already been given to the industry.

The coconut industry is beset with problems primarily relating to low incorne. The current programme is geared to overcome this problem to benefit the grower and the country. 


\section{REFERENCES}

Anon. (1984) Opportunities for intercropping - Special Report No. 2. Ministry of Finance and Planning, Colombo.

Balakrishnamurthi, T. S. (1969) Isotope studies on efficiency of fertilizer utilization by coconut palms. Ceylon Cocon Q 20:111-122.

Cock, M. J. W. and P. A. C. R. Perera (1988) Biological control of Opisina arenosella Walker (Lepidoptera; Oecophoridae) Occasional Publication Series No. 2. CRI 44 pp.

De Silva M. A. T., B. S. A. F. Mendis, P. A. D. G. A. Appuhamy \& G. D. George (1974) Micronutrients in the nutrition of coconut II. Effect of micronutrient deficiences in the distribution of $\mathrm{Fe}, \mathrm{Mn}, \mathrm{Cu}, \mathrm{Zn}$ and $\mathrm{B}$ in leaf components of coconut seedlings. Ceylon Cocon Q 25: 128-138.

De Silva N. T. M. H. and C. A. Tisdell (1981) Response of coconut to fertilizer and advice to Sri Lankan grower: an aggregative approach. Ceylon Cocon Q 32: 72-79.

Dharmadikari P. R., P. A. C. R. Perera and T. M. F. Hassen (1977) A short account of the biological control of Promecotheca curning (Col: Hispidae), the coconut leaf miner in Sri Lanka. Entomophaga 22: 348.

Ferdinandez, D. E. F. (1979) In Annual Report of the CRI for 1979. Ceylon Cocon Q 31: 45-50.

Fernando H. E. (1972) Concluding report on control of Promecotheca cumingi the introduced pest of coconut. Ceylon Cocon Q 23: 116-22.

Fernando L. C. P. and P. Kanagaratnam (1987) In annual Report of the Coconut Research Institute of Sri Lanka for 1987 p. 133.

Fernando. W. M. U. and M. R. T. Wickramaratne (1988) In Annual Report of the CRI for 1987 pp 55.

Gunathilaka, H. A. J. (1986) Mixed cropping models for coconut lands. Coconut Bulletin 3(1) 29-31.

Harland, S. C. (1957) The improvement of the coconut palm by breeding and selection-Bulletin No. $15, \mathrm{CRI}$.

Henry Nimal P. A. (1984) Protect small holdings from drought. Coconut Bulletin 1: 11-14.

Jayasekera, K. S. (1988) Status of nutritional deficiencies of coconut in Sri Lanka. Working Group on Coconut Nutritional Deficiencies RAS 80/032, Davao, Philippines.

Jayasekera K. S. and P Loganathan (1981) Effect of husk burial in coconut lands on soil moisture conservation. Proc. Sri Lanka Assn. for the Advt. Science 1981 p 28.

Kanagaratman P. and J. L. J. G Pinto (1985) Effect of monocrotophos on the leaf eating caterpillar, Opisina arenosella Walk when injected into the trunk of the coconut palm. COCOS 3; 9-15.

Liyanage D. V. (1959) In Annual Report of the CRI for 1959.

Liyanage, D. V. (1963) In Annual Report of the CRI for 1963. 
Liyanage, D. V. (1967) Identification of genotypes of coconut palms suitable for breeding. Exp. Agric 3: 205-210.

Liyanage, D. V. (1989) Strategy for popularization of high-yielding varieties among small-holders. XXVI COCOTECH, Asian \& Pacific Coconut Community, Indonesia.

Liyanage, D. V. and K. I. Sakai (1960) Heritabilities of certain yield characters of the coconut palm. J Genetics 57; 245-252.

Liyanage D. V. ; M. R. T. Wickramaratne and C. Jayasekera (1988) Coconut Breeding in Sri Lanka : A Review. $\operatorname{COCOS} 6$ : 1-26.

Liyanage L. V. K. (1985) Rationale for intercropping. Coconut Bulletin 2(2): 31-34

Liyanage L. V. K. (1987) Moisture conservation in coconut lands. Coconut Bulletin 4(2) 1-5.

Liyanage, M. de S. (1988) Use of coir dust for moisture conservation. Coc Bull 5; 18-20.

Liyanage M. de S., K. G. Tejwani and P. K. R. Nair (1984) Intercropping under coconuts in Sri Lanka Agroforestry Systems 2: 215-28.

Loganathan, P. (1977) Profitability of fertilizing young coconut: results of three long-term field experiments. Ceylon Cocon Q 28; 68-72.

Loganathan P and T. S. Balakirishnamurthi (1975) Response of coconut to N, P and K fertilizer application from the time of field planting on a lateritic gravel soil in Sri Lanka. Ceylon Cocon Q 26: 89-98.

Loganathan P and T. S. Balakrishnamurthi (1979) Effects of N P K fertilizers on the yield and leaf nutrient concentration of adult coconut on a laterictic gravelly soil in Sri Lanka. Ceylon Cocon Q 30: 81-89.

Manthriratne M. A. P. (1971) Some results of field experimentation with typica $\mathrm{x}$ nana $\mathrm{F}_{1}$, ybrids. Ceylon Cocon Q 22: 107-43.

Manthriratne, M.A.P. \& V. Abeywardene (1979) Planting densities and planting systems for coconut, Cocos nucifera L. 2. Studies of yield characteristics and the economics of planting at different densities. Ceylon Cocon Q 30: 107-115.

Mahindapala R. (1978) Pests and diseases of coconut and their control Ceylon Cocon Q 29: 97-102.

Mahindapala R. (1984) Measures to minimize drought damage in coconut plantations Coconut Bulletin 1; 1-4.

Mahindapala R. (1985) Biological Control - the past, the present and the future. Proc Sri Lanka Ass. Advmt Sci 41 (2) 33-44.

Mahindapala R. (1988) Status of coconut diseases and disorders in Sri Lanka. Proc. Of COCOTECH meeting; March, 1988; Asian \& Pacific Coconut Community, Indonesia.

Mahindapala, R. 9 J. K. F. Kirtisinghe and J. L. J. G. Pinto (1982) Biological control of Eupatorium odoratum. Ceylon Cocon Q 33: 103-109. 
Mathes, D. T. (1986) Economics of intercropping coffee, cacao and pepper under coconut. Coconut Bulletin 3(1); 9-11.

Nathanael, W.R.N. (1954) The manufacture and characteristics of Ceylon Arrack Ceylon Cocon Q. 5: 77-83.

Nathanael, W. R. N. (1955) The commercial possibilities of manufacture of high grade vinegar from coconut toddy. Ceylon Cocon Q 6; 81-85.

Nathanael, W.R.N. (1961) Coconut nutrition and fertilizer requirements: the plant approach. Ceylon Cocon Q. 12: 101-120.

Nathanael, W. R. N. (1966) Moisture and other quality factors of copra. Ceylon Cocon Q 17: 1-14.

Nathanael, W.R.N. (1967) The Application of fertilizers to adult coconut palms in relation to theoretical concepts Ceylon Cocon Q. 18: 5-30.

Nathanael, W.R.N. (1970 a) Coconut toddy tapping and cottage manufacture of treacle and jaggery, Ceylon Cocon PIrs Rev. 6: 63-65.

Nathanael W.R.N. (1970 b) Non-conventional uses and processing techniques for coconut products. Ceylon Cocon Q. 21: 99-106.

Perera P. A. C. R., M.P. Hassell and H.C.J. Godfray (1988) Population dynamics of the coconut caterpillar, Opisina arenosella Walker (Lepidoptera; Xyloryctidae) in Sri Lanka. Bull ent Res. 78; 479-492.

Perera, P. A. C. R., R. Mahindapala and U. Pethiyagoda (1989) A technique for application of systemic insecticide. COCOS 7 (In press).

Pieris, W.V.D. (1934) Studies on coconut palm - 1 Trop Agric 82: 75-97.

Pieris, W.V.D. (1935) Studies on coconut palm - 2 Trop Agri 85: 208-220.

Pieris, W.V.D. (1943) In Annual Report of the CRI for 1943.

Raghavan, T S (1948) In Annual Report of the CRI for 1948.

Ran atunga A. S., L. V. K. Liyanage and R. A. J. R. Perera (1988) Coconut-based cropping systems in the wet and wet intermediate zones: Present constraints and prospects. Occasional Publication Series No. 1, Coconut Research Institute of Sri Lanka.

Salgado, M. L. M. (1937) In Annual Report of the CRI for 1937.

Salgado, M. L. M. (1952) Potash and its importance in coconut manuring Ceylon Cocon Q 3(4); 191-92.

Salgado M. L. M. (1957) Preliminary studies on the chemistry of cattle manuring on coconut estates. Trop. Agri 107: 218-224.

Salgado M. L. M. (1958) Land use and soil and water relations with reference to coconut cultivation Ceylon Cocon Q 9; 11-19. 
Santhirasegaram, K. and D. E. F. Ferdinandez (1967) Yield and competitive relationship between two species of Brachiaria in association. Trop Agric 44; 229-234.

Shanmuganathan R. T (1985) Use of organic manure. Coconut Bulletin 2; 19-20.

Wickremaratne, M. - R. T. (1988) Assessment of experience with new varieties of coconut - Sri Lanka AENVC No.3, Asian \& Pacific Coconut Community, Indonesia. 